\title{
The Prediction of Future Profitability Using Life Cycle Theory Based on Cash Flow Pattern
}

\author{
Zahra Hashemi Oskouei ${ }^{1,2, *}$, Rasoul Baradaran Hasan Zadeh ${ }^{2}$ \\ ${ }^{1}$ Department of Accounting, East Tehran Branch, Islamic Azad University, Iran \\ ${ }^{2}$ Department of Accounting, East Azarbaijan Branch, Islamic Azad University of Tabriz, Iran
}

Copyright $\bigcirc 2017$ by authors, all rights reserved. Authors agree that this article remains permanently open access under the terms of the Creative Commons Attribution License 4.0 International License

\begin{abstract}
This paper aims to predict the future profitability of a firm using the life cycle theory based on the cash flow statement. In this study, changes in return on net operating assets were considered as a dependent variable. The profitability factors were independent variables and the risk factors were used as a control variable in order to examine the prediction of the future profitability. The statistical samples were classified into the stages of introduction, growth, maturity, shake-out and decline by using cash flow patterns. The results of 1,123 (firms - years) over the time period of 2002 and 2011 showed that the return of the net operating assets, their variations and changes in the asset turnover at different stages of the life cycle have an impact on the future profitability of the firms.
\end{abstract}

Keywords Prediction, Profitability, Firm's Life Cycle, Cash Flow Pattern

\section{Introduction}

The main goal of financial reporting is to provide useful information for investors, creditors, customers and other users for making financial decisions. Thus, the evaluation of accounting information in predicting future profitability has been always studied and presented in financial accounting studies $[1,2]$. A firm's cash flow pattern is associated with the market efficiency with respect to the stock price [3]. Also, cash flow patterns identify differential behaviors in the persistence and intertemporal convergence patterns of profitability. This is because the life cycle stages influence the profitability of a firm and their interactions with the profitability criteria [4].

The firm's life cycle theory assumes that firms and economic entities grow like human beings; and thus, have life cycle curves. In each stage of the life cycle, there are certain problems related to that stage. Also, certain problems are created when transferring from one stage into the next one. Several studies have examined the impact of the firm's life cycle on the accounting information [3, 5-9]. According to Gort \& Klepper [10], the life cycle includes 5 stages in a market: Introduction, Growth, Maturity, Shake-out and Decline.

The previous studies have documented that profitability measures mean-revert over time [4, 11-14] and understanding the evolution of profitability can improve predictability. Haghighat \& Ghorbani [15] employed the Anthony's \& Ramesh's method [5] to assess two performance measures of profit and cash flow, and their relation with a firm's life cycle. Using the same method, Dehdar [16] studied valuation models based on profit and cash flow in a firm's life cycle. They focused only on the operating activities segment of the cash flow statement. The results showed that in the growth and maturity stages, valuating patterns based on profit and accruals result in a higher descriptive power compared to patterns based on the operating cash flow, investment, and financing. It was vice versa in the decline stage. To predict the profitability more accurately, a more precise method should be used for the life cycle and its association with all the three layers of the cash flow statement.

Omrani \& Karami [17] studied the effect of the firm's life cycle and conservatism on the firm value. Their findings showed that in the growth and maturity stages, the investors consider net operating assets and extraordinary operating profits of conservative companies to be more important. This is vice versa at the decline stage. The results reported in another study [18] showed that the variables of life cycle and firm size are effective factors in the relationship between profitability and return.

Park \& Chen [19] presented some evidence showing that conservatism and life cycle have common effects on the accounting information and value of a firm. Thanatawee [20] studied the "life cycle theory and free cash flows" of dividends policies in the firms listed in the Stock Exchange of Thailand. The results showed that the bigger and more profitable companies tend to pay more dividends by having more free cash flows and logical earnings than capital.

The previous studies on the prediction of future profitability in different stages of a firm's life cycle have not 
employed the cash flow pattern method of Dickinson [3]. Taking into account the advantage of this method over the Anthony's \& Ramesh's method [3], valuable information can be provided to identify the role of cash flow in the stages of life cycle. Positives and negatives of each cash flow segments can indicate the expected financial policies of each stage of the life cycle.

The main aim of this research was to study the relationship between cash flow, future performance, and firm's life cycle. Studying the stages in the firm's life cycle can provide valuable insights for a better understanding of the firm's financial performance. Therefore, more accurate predictions can be made if we could separate and evaluate the stages of the firm's life cycle more efficiently.

\section{Methodology}

In this study, both independent and dependent variables have occurred in the past; thereby, it is post incidental.

\subsection{Cash Flow Patterns Method}

The cash flow patterns method is one of the new methods proposed by Dickinson [3] to isolate the stages in a firm's life cycle. In this research, we have used this method to isolate the stages in the life cycle of firms, as given in Table 1. Using positive or negative signs of each of the stages, 8 possible states $\left(2^{3}=8\right)$ are isolated into 5 life cycle stages. Following the Dickinson's cash flow patterns method [3], 8 states were considered for the firm's life cycle; and therefore, for 8 possible states of the firm's life cycle, some patterns (positive and negative signs of levels in cash flow statements) were taken into consideration. If these patterns (signs of levels in the cash flow statements) are resided in any of the 8 possible states of firms in Table 1, the firm will fall into the specified stage of the life cycle. As can be seen in the table, there are 3 states for the shake-out stage, and 2 states for the decline stage, regarding the signs present in different levels of the cash flow statement.

Table 1. Isolation of the stages in firm's life cycle

\begin{tabular}{|c|c|c|c|c|c|c|c|c|}
\hline & 1 & 2 & 3 & 4 & 5 & 6 & 7 & 8 \\
\hline & Introduction & Growth & Maturity & Shake-out & Shake-out & Shake-out & Decline & Decline \\
\hline Predicted signs & & & & & & & & \\
\hline $\begin{array}{c}\text { Cash flows from } \\
\text { operating activities }\end{array}$ & - & + & + & - & + & + & - \\
\hline $\begin{array}{c}\text { Cash flows from } \\
\text { investment activities }\end{array}$ & - & - & - & - & + & + & + \\
\hline $\begin{array}{c}\text { Cash flows from } \\
\text { financing activities }\end{array}$ & + & + & - & - & + & - & + \\
\hline
\end{tabular}

\subsection{Statistical Population, Sampling, and Samples}

In this research, the statistical population includes those firms that were listed in Iran's Stock Exchange over the time period of 2002-2011, the following criteria were applied to choose appropriate samples using a deletion method.

1) The samples selected for the present research should not be chosen from investment firms, financial intermediaries, holdings, banks, or leasings.

2) To establish comparability, fiscal year of the firms should end on 21 March.

3) Financial information of the firms for the period under investigations should be accessible.

4) Firms should not have changed their fiscal year during the financial period.

5) Firms should not have been chosen from those put aside from Stock Exchange.

Accordingly and after applying the above limitations, 114 firms and 1123 data sets for the time period between 2002 and 2011 were selected and used as statistical samples for the present research. The data sets were obtained from the financial statements of the firms including balance statements, income statements and cash flow statements. These financial statements were accessed from the Stock Exchange Organization of Iran. SPSS software was used to analyze the data. To test our research hypotheses we used the following models:

$$
\begin{aligned}
& \text { 1. } \triangle R N O A_{t+1}=\alpha+\beta_{1} R N O A_{t}+\beta_{2} \Delta R N O A_{t}+\beta_{3} G R N O A_{t}+\beta_{4} \Delta A T O_{t}+\beta_{5} \Delta P M_{t}+\beta_{6} E P S_{t} \\
& +\beta_{7} A G E_{t}+\beta_{8} M / B_{t}+\beta_{9} L E V_{t}+\beta_{10} \text { Beta }_{t}+\beta_{11} S I Z E_{t}+\beta_{12}(\delta R E T)_{t}+\sum_{k=1}^{5} D_{k} L C_{t}+\varepsilon_{t+1}
\end{aligned}
$$




$$
\begin{aligned}
& \begin{array}{l}
\text { 2. } \triangle R N O A_{t+1}=\alpha+\beta_{1} R N O A_{t}+\beta_{2} \Delta R N O A_{t}+\beta_{3} G R N O A_{t}+\beta_{4} \Delta A T O_{t}+\beta_{5} \Delta P M_{t}+\beta_{6} E P S_{t}+\beta_{7} A G E_{t} \\
+\beta_{8} M / B_{t}+\beta_{9} L E V_{t}+\beta_{10} \text { Beta }_{t}+\beta_{11} S I Z E_{t}+\beta_{12}(\delta R E T)_{t}+\sum_{k=1}^{5} D_{k} L C_{t}+ \\
\sum_{k=1}^{5} \delta_{5 k}\left(\Delta A T O_{t} \times L C_{k}\right)+\sum_{k=1}^{5} \delta_{5 k}\left(\Delta P M_{t} \times L C_{k}\right)+\varepsilon_{t+1}
\end{array} \\
& \text { 3. } \Delta R N O A_{t+1}=\alpha+\beta_{1} R N O A_{t}+\beta_{2} \Delta R N O A_{t}+\beta_{3} G R N O A_{t}+\beta_{4} \Delta A T O_{t}+\beta_{5} \Delta P M_{t}+\beta_{6} E P S_{t} \\
& +\beta_{7} A G E_{t}+\beta_{8} M / B_{t}+\beta_{9} L E V_{t}+\beta_{10} \text { Beta }_{t}+\beta_{11} S I Z E_{t}+\beta_{12}(\delta R E T)_{t t}+\varepsilon_{t+1}
\end{aligned}
$$

The dependent variable used in the present study, which is used as a criterion to predict the future profitability, was the change in return of the net operating assets. Nissim and Penman [4] reported that RNOA is a more relevant dependent variable for predicting future profitability when compared to ROA or ROE. Therefore, RNOA was used as the dependent variable in this study. The independent variables, control variables, and adjusting variables are described in Tables 2,3 , and, 4 , respectively.

Table 2. Independent variables.

\begin{tabular}{|c|c|c|}
\hline Independent variables & Descriptions & Symbol \\
\hline Return of net operating assets & operating profit divided by average net operating assets & RNOA \\
\hline Growth of operating assets & changes in fixed assets divided by total firm stocks' value at the end of period & GrNOA \\
\hline Changes in assets' flow & net sales divided by average net operating assets & $\Delta$ ATO \\
\hline Changes in profit margin & operating profit divided by net sales & $\Delta$ PM \\
\hline Earnings per share & profit belonging to common stockholders divided by the number of stocks at hand & EPS \\
\hline Firm's life cycle stages & cash flow pattern method divides the stages into introduction, growth, maturity, \\
shake-out, and decline. & LC \\
\hline
\end{tabular}

Table 3. Control variables.

\begin{tabular}{|c|c|c|}
\hline Control variables & Descriptions & Symbol \\
\hline $\begin{array}{c}\text { Market value to book value } \\
\text { of equity ratio }\end{array}$ & total market value of firm stocks divided by equity value in balance sheet in fiscal year & M/B \\
\hline Debt to equity ratio & total debts divided by equity at the end of financial period & Leverage \\
\hline Market model basis & $\begin{array}{c}\mathrm{B}=\mathrm{COV}\left(\mathrm{R}_{\mathrm{it}}, \mathrm{R}_{\mathrm{mt}}\right) / \sigma^{2}\left(\mathrm{R}_{\mathrm{mt}}\right) \\
\mathrm{R}_{\mathrm{m}} \text { is market portfolio return and } \mathrm{R}_{\mathrm{it}} \text { is return per share i during time t. }\end{array}$ & $\mathrm{B}$ \\
\hline Firm size & logarithm of market value of equity & SIZE \\
\hline Age & firm age from the establishment & AGE \\
\hline $\begin{array}{c}\text { Criterion deviation from } \\
\text { monthly stocks return }\end{array}$ & & $\Sigma$ ret \\
\hline
\end{tabular}

Table 4. Adjusting variables.

Adjusting variables

$(\triangle \mathrm{ATO} * \mathrm{LC})=$ changes of assets flows multiplied by stages in life cycle regarding cash flow pattern method

$(\triangle P M * \mathbf{L C})=$ changes of profit margins multiplied by stages in life cycle regarding cash flow pattern method 


\subsection{Hypothesis Development}

First hypothesis: Profitability criteria are able to predict future profitability in different stages of the life cycle extracted from cash flow patterns. Minor hypotheses of the first hypothesis include:

- Changes in the operating assets turnover are able to predict future profitability in different stages of the life cycle extracted from the cash flow patterns.

- Profit margin is able to predict future profitability in different stages of the life cycle extracted from the cash flow patterns.

- $\quad$ Earnings per share are able to predict future profitability in different stages of the life cycle extracted from the cash flow patterns.

- Growth in the operating assets is able to predict future profitability in different stages of the life cycle extracted from the cash flow patterns.

- Return of the net operating assets and their changes are able to predict future profitability in different stages of the life cycle extracted from the cash flow patterns.

Second hypothesis: The ability to predict future profitability in different stages of the life cycle extracted from the cash flow patterns is different for different stages.

\section{Testing the First Hypothesis and its Minor Hypotheses}

To test the first hypothesis and its minor hypotheses, we have adjusted regression model 1 [21] to measure the ability to predict future profitability for the statistical samples of each stage including: introduction, growth, maturity, shake-out, and decline. In this model, we used the changes in return of the net operating assets in two levels of fiscal year, $t+1$ and $t$, respectively. This is because the determined current profitability has a direct relationship with the future profitability prediction. Thus, if a firm is in its introduction stage; code 1, in growth stage; code 2, maturity stage; code 3 , shake-out stage; code 4 , and decline stage; code 5 will be assigned.
Penman \& Zhang [22] claimed, based on their research findings, that there is a negative relationship between the profit margin and future profitability. The results showed that if the increase in the profit margin is due to a reduction in the current operating costs, it is unbearable for the firm and it has a negative relationship with the future profitability. Therefore, in regression model 2 and due to the effect of these two variables in the future profitability prediction, these two variables were adjusted with the life cycle variable.

\section{Testing the Second Hypothesis}

To test the second hypothesis, regression model 2 was adjusted for each of the stages in the life cycle. For each of the stages, an adjusted identification coefficient $\left(R^{2}\right)$ was achieved that represented the ability to predict the future profitability for each of the stages mentioned. Then, it was concluded that every stage which has a greater adjusted identification coefficient $\left(R^{2}\right)$ will have a more prediction ability.

\section{Results}

\subsection{Descriptive Statistics}

Table 5 shows the descriptive statistics of independent, dependent, and base variables of the categorization of the firms into the life cycle stages in isolation as: introduction, growth, maturity, shake-out, and decline stages.

The results of the correlation test between the research variables in Table 6 , showed that the changes of return on the net operating assets have a positive correlation with the return on the operating assets and a negative and meaningful correlation with changes in the profit margin. Return on the net operating assets had a positive and meaningful correlation with the changes in the assets flow, changes in the profit margin, market value to book value ratio, and the firm size.

Table 5. Descriptive statistics.

\begin{tabular}{|c|c|c|c|c|c|c|}
\hline Variable & Symbol & $\begin{array}{c}\text { No. of } \\
\text { observations }\end{array}$ & Average & $\begin{array}{l}\text { Standard } \\
\text { deviation }\end{array}$ & Minimum & Maximum \\
\hline Return of net operating assets & RNOA & 1121 & 0.145 & 0.218 & -0.35 & 1.84 \\
\hline Profit margin & PM & 1122 & 0.194 & 0.236 & -2.45 & 1.26 \\
\hline Assets' flow & ATO & 1122 & 0.734 & 0.880 & 0.000 & 2.84 \\
\hline Growth of operating assets & GRNOA & 1122 & 0.077 & 0.365 & -1.75 & 2.78 \\
\hline Changes in return of net operating assets & $\triangle R N O A$ & 1122 & 0.032 & 0.154 & -1.22 & 1.81 \\
\hline Changes of assets' flow & $\triangle A T O$ & 1121 & -0.072 & 0.347 & -2.78 & 1.38 \\
\hline Market value to book value ratio of equity & $M / B$ & 1122 & 2.963 & 4.438 & -10.15 & 12.05 \\
\hline Financial leverage & LEV & 1122 & 0.635 & 1.919 & -2.15 & 7.32 \\
\hline beta (systematic risk) & Beta & 1122 & 0.644 & 3.523 & -3.72 & 7.88 \\
\hline Firm size & SIZE & 1122 & 5.626 & 0.798 & 3.66 & 9.22 \\
\hline Firm age & Age & 1122 & 34.910 & 10.896 & 2 & 60 \\
\hline
\end{tabular}


Table 6. Correlations between Variables.

\begin{tabular}{|c|c|c|c|c|c|c|c|c|c|c|c|c|}
\hline Variable & Sign & $\triangle R N O A$ & RNOA & GRNOA & $\triangle A T O$ & $\triangle P M$ & Age & MB & LEV & Beta & Size & $\delta(R E T)$ \\
\hline $\begin{array}{c}\text { Return of } \\
\text { net } \\
\text { operating } \\
\text { assets }\end{array}$ & $\triangle R N O A$ & 1 & & & & & & & & & & \\
\hline $\begin{array}{l}\text { Return of } \\
\text { net } \\
\text { operating } \\
\text { assets }\end{array}$ & RNOA & $\begin{array}{c}0.102 \\
* *\end{array}$ & 1 & & & & & & & & & \\
\hline $\begin{array}{c}\text { Growth of } \\
\text { operating } \\
\text { assets }\end{array}$ & GRNOA & 0.001 & -0.005 & 1 & & & & & & & & \\
\hline $\begin{array}{l}\text { Changes in } \\
\text { assets' flow }\end{array}$ & $\triangle A T O$ & -0.047 & $\begin{array}{c}0.133 \\
* *\end{array}$ & 0.049 & 1 & & & & & & & \\
\hline $\begin{array}{l}\text { Changes in } \\
\text { profit } \\
\text { margin }\end{array}$ & $\triangle P M$ & $\begin{array}{c}-0.070 \\
*\end{array}$ & $\underset{* *}{0.188}$ & 0.020 & $\begin{array}{c}0.241 \\
* *\end{array}$ & 1 & & & & & & \\
\hline Firm age & Age & -0.014 & 0.001 & $\begin{array}{c}\mathbf{0 . 0 8 8} \\
* *\end{array}$ & $\begin{array}{c}-0.103 \\
* *\end{array}$ & 0.012 & 1 & & & & & \\
\hline $\begin{array}{c}\text { Market } \\
\text { value to } \\
\text { book value } \\
\text { ratio }\end{array}$ & MB & -0.029 & $\begin{array}{c}0.196 \\
* *\end{array}$ & -0.049 & $\underset{* *}{0.101}$ & -0.031 & $\begin{array}{c}-0.128 \\
* *\end{array}$ & 1 & & & & \\
\hline Leverage & LEV & -0.035 & -0.025 & $\begin{array}{c}\mathbf{0 . 0 8 8} \\
* *\end{array}$ & -0.024 & 0.009 & 0.051 & $\begin{array}{l}0.070 \\
*\end{array}$ & 1 & & & \\
\hline $\begin{array}{c}\text { beta } \\
\text { (systematic } \\
\text { risk) }\end{array}$ & Beta & 0.013 & 0.052 & -0.039 & 0.003 & 0.019 & 0.003 & 0.045 & -0.013 & 1 & & \\
\hline Firm size & Size & 0.023 & $\begin{array}{c}0.432 \\
* *\end{array}$ & $\begin{array}{c}0.264 \\
* *\end{array}$ & $\begin{array}{c}-0.065 \\
*\end{array}$ & $\begin{array}{c}0.069 \\
*\end{array}$ & $\begin{array}{c}0.216 \\
* *\end{array}$ & $\begin{array}{c}0.169 \\
* *\end{array}$ & $\begin{array}{c}0.081 \\
* *\end{array}$ & 0.008 & 1 & \\
\hline $\begin{array}{c}\text { Stock } \\
\text { return's } \\
\text { criterion } \\
\text { deviation } \\
\end{array}$ & $\delta(R E T)$ & 0.022 & -0.034 & $\begin{array}{c}-0.078 \\
* *\end{array}$ & 0.037 & 0.033 & $\begin{array}{c}-0.064 \\
*\end{array}$ & 0.058 & -0.033 & $\begin{array}{c}0.260 \\
* *\end{array}$ & $\begin{array}{c}-0.122 \\
* *\end{array}$ & 1 \\
\hline
\end{tabular}

\subsection{Results of Testing the First Hypothesis}

According to the first hypothesis, profitability criteria are able to predict future profitability. To test the first hypothesis and its minor hypotheses, we used regression models 1 and 2 . The results of testing model (1) are presented in Table 7. The p-value was 0.007 which indicates that the total regression for model 1 was significant. The test results showed that the criteria of profitability, return of the net operating assets, and its changes and also changes in the operating assets flow had the ability to predict future profitability in a way that return of the net operating assets has a meaningful and positive effect. The changes in the return of the net operating assets and changes in the operating assets flow had meaningful and negative effects on the future profitability. Other independent and control variables entered into the model did not have a meaningful effect on the ability to predict the future profitability.

The results of testing model (2) regarding the first hypothesis are presented in Table 8 . The total regression for model 2 was also significant with the p-value of 0.004 . The test results showed that the criteria of profitability, return of the net operating assets, and its changes and also changes in the operating assets turnover had the ability to predict the future profitability in a way that return of the net operating assets has a meaningful and positive effect. The changes in return of the net operating assets and changes in the operating assets turnover had meaningful and negative effects on the future profitability. Also, the test results showed that the adjustment of the operating assets turnover through the firm's life cycle had a positive and meaningful effect on the future profitability. On the contrary, the adjustment of changes in the profit margin through the life cycle had meaningless and positive effects of the future profitability. The other independent and control variables entered into the model did not have a meaningful effect on the ability to predict the future profitability. 
Table 7. Results of testing first hypothesis and minor hypotheses of the first hypothesis of model 1.

\begin{tabular}{|c|c|c|c|c|c|c|c|}
\hline \multirow{2}{*}{ Variable } & \multirow{2}{*}{ Symbol } & \multirow{2}{*}{\multicolumn{2}{|c|}{$\underset{\text { (Beta) }}{\text { Coefficient }}$}} & \multirow{2}{*}{ t statistic } & \multirow{2}{*}{ P Value } & \multicolumn{2}{|c|}{ Co-linearity study } \\
\hline & & & & & & Special amounts & Status index \\
\hline Fixed amount & $\alpha$ & & - & 0.822 & 0.411 & - & - \\
\hline $\begin{array}{c}\text { Return of net } \\
\text { operating assets }\end{array}$ & $(\mathrm{RNOA}) \beta_{1}$ & & 0.102 & 2.503 & 0.012 & 0.592 & 1.690 \\
\hline $\begin{array}{c}\text { Changes in return } \\
\text { on net operating } \\
\text { assets }\end{array}$ & $(\triangle R N O A) \beta_{2}$ & & -0.100 & -3.144 & 0.002 & 0.971 & 1.030 \\
\hline $\begin{array}{c}\text { Growth of } \\
\text { operating assets }\end{array}$ & $(\mathrm{GRNOA}) \beta_{3}$ & & -0.020 & -0.639 & 0.523 & 0.978 & 1.023 \\
\hline $\begin{array}{l}\text { Changes in assets' } \\
\text { flow }\end{array}$ & $(\triangle A T O) \beta_{4}$ & & -0.105 & -3.097 & 0.002 & 0.854 & 1.171 \\
\hline $\begin{array}{l}\text { Changes in profit } \\
\text { margin }\end{array}$ & $(\triangle P M) \beta_{5}$ & & 0.014 & 0.409 & 0.682 & 0.896 & 1.117 \\
\hline Earnings per share & $(\mathrm{EPS}) \beta_{6}$ & & -0.046 & -1.287 & 0.198 & 0.761 & 1.315 \\
\hline Firm age & $(\mathrm{AGE}) \beta_{7}$ & & -0.017 & -0.535 & 0.593 & 0.929 & 1.077 \\
\hline $\begin{array}{l}\text { market value to } \\
\text { book value ratio }\end{array}$ & $(\mathrm{M} / \mathrm{B}) \beta_{8}$ & & -0.027 & -0.765 & 0.444 & 0.791 & 1.264 \\
\hline Leverage & $(\mathrm{LEV}) \beta_{9}$ & & -0.017 & -0.547 & 0.584 & 0.982 & 1.019 \\
\hline $\begin{array}{c}\text { Beta (systematic } \\
\text { risk) }\end{array}$ & (Beta) $\beta_{10}$ & & 0.017 & 0.499 & 0.618 & 0.842 & 1.188 \\
\hline Firm size & $($ Size $) \beta_{11}$ & & 0.005 & 0.123 & 0.902 & 0.567 & 1.764 \\
\hline $\begin{array}{c}\text { Stock return's } \\
\text { criterion deviation }\end{array}$ & $\delta(R E T) \beta_{12}$ & & -0.015 & -0.463 & 0.643 & 0.920 & 1.087 \\
\hline Firm's life cycle & $\sum_{k=1}^{5} D_{k} L C$ & & -0.017 & -0.532 & 0.595 & 0.970 & 1.031 \\
\hline \multirow[t]{2}{*}{$\begin{array}{c}\text { Total regression } \\
\text { model }\end{array}$} & F statistic & P-Value & \multicolumn{2}{|c|}{$\begin{array}{c}\text { Durbin-Watson } \\
\text { statistic }\end{array}$} & \multicolumn{3}{|c|}{$\begin{array}{c}\text { Identification coefficient and adjusted identification } \\
\text { coefficient }\end{array}$} \\
\hline & 2.225 & 0.007 & \multicolumn{2}{|c|}{2.046} & \multicolumn{3}{|c|}{$\begin{aligned} \mathrm{R}^{2} & =0.028 \\
\operatorname{AdiR}^{2} & =0.016\end{aligned}$} \\
\hline
\end{tabular}

Table 8. Results of testing first hypothesis and minor hypotheses of the first hypothesis of model 2.

\begin{tabular}{|c|c|c|c|c|c|c|}
\hline \multirow{2}{*}{ Variable } & \multirow{2}{*}{ Symbol } & \multirow{2}{*}{$\begin{array}{l}\text { Coefficient } \\
\text { (Beta) }\end{array}$} & \multirow{2}{*}{ t statistic } & \multirow{2}{*}{ P Value } & \multicolumn{2}{|c|}{ Co-linearity study } \\
\hline & & & & & Special amounts & Status index \\
\hline Fixed amount & $\alpha$ & - & 0.740 & 0.459 & - & - \\
\hline $\begin{array}{c}\text { Return of net } \\
\text { operating assets }\end{array}$ & $(\mathrm{RNOA}) \beta_{1}$ & 0.101 & 2.478 & 0.013 & 0.591 & 1.691 \\
\hline $\begin{array}{l}\text { Changes in return } \\
\text { on net operating } \\
\text { assets }\end{array}$ & $(\triangle R N O A) \beta_{2}$ & -0.108 & -3.366 & 0.001 & 0.947 & 1.056 \\
\hline $\begin{array}{c}\text { Growth of } \\
\text { operating assets }\end{array}$ & $(\mathrm{GRNOA}) \beta_{3}$ & -0.23 & -0.731 & 0.465 & 0.976 & 1.024 \\
\hline $\begin{array}{l}\text { Changes in assets' } \\
\text { flow }\end{array}$ & $(\triangle A T O) \beta_{4}$ & -0.238 & -3.127 & 0.002 & 0.169 & 5.911 \\
\hline $\begin{array}{l}\text { Changes in profit } \\
\text { margin }\end{array}$ & $(\triangle P M) \beta_{5}$ & -0.029 & -0.340 & 0.734 & 0.136 & 7.368 \\
\hline Earnings per share & (EPS) $\beta_{6}$ & -0.046 & -1.294 & 0.196 & 0.758 & 1.319 \\
\hline Firm age & (AGE) $\beta_{7}$ & -0.016 & -0.497 & 0.619 & 0.927 & 1.078 \\
\hline $\begin{array}{l}\text { market value to } \\
\text { book value ratio }\end{array}$ & $(\mathrm{M} / \mathrm{B}) \beta_{8}$ & -0.026 & -0.733 & 0.464 & 0.791 & 1.264 \\
\hline Leverage & (LEV) $\beta_{9}$ & -0.017 & -0.539 & 0.590 & 0.981 & 1.020 \\
\hline $\begin{array}{c}\text { Beta (systematic } \\
\text { risk) }\end{array}$ & (Beta) $\beta_{10}$ & 0.015 & 0.431 & 0.666 & 0.840 & 1.190 \\
\hline Firm size & (Size) $\beta_{11}$ & 0.004 & 0.107 & 0.915 & 0.567 & 1.765 \\
\hline $\begin{array}{c}\text { Stock return's } \\
\text { criterion deviation }\end{array}$ & $\delta(R E T) \beta_{12}$ & -0.019 & -0.582 & 0.561 & 0.917 & 1.091 \\
\hline Firm's life cycle & $\sum_{k=1}^{5} D_{k} L C$ & -0.003 & -0.101 & 0.920 & 0.932 & 1.073 \\
\hline $\begin{array}{l}\text { Adjustment of } \\
\text { assets' flow and } \\
\text { life cycle }\end{array}$ & $\sum_{k=1}^{5} \delta_{k}\left(\triangle A T O_{t} \times L C_{k}\right)$ & 0.146 & 1.983 & 0.044 & 0.172 & 5.830 \\
\hline $\begin{array}{l}\text { Adjustment of } \\
\text { profit margin and } \\
\text { life cycle }\end{array}$ & $\sum_{k=1}^{5} \delta_{k}\left(\Delta P M_{t} \times L C_{k}\right)$ & 0.046 & 0.542 & 0.588 & 0.136 & 7.345 \\
\hline
\end{tabular}

\begin{tabular}{|c|c|c|c|c|}
\hline $\begin{array}{c}\text { Total regression } \\
\text { model }\end{array}$ & F statistic & P-Value & $\begin{array}{c}\text { Durbin-Watson } \\
\text { statistic }\end{array}$ & $\begin{array}{c}\text { Identification coefficient and adjusted identification } \\
\text { coefficient }\end{array}$ \\
\hline & 2.245 & 0.004 & 2.054 & $\begin{array}{c}\mathrm{R}^{2}=0.033 \\
\mathrm{AdiR}^{2}=0.018\end{array}$ \\
\hline
\end{tabular}




\subsection{Results of Testing the Second Hypothesis}

The second hypothesis states that: the ability to predict future profitability in different stages of the life cycle extracted from the cash flow patterns is different for different stages. To test this hypothesis, regression model 3 was adjusted in different stages of the life cycle (introduction, growth, maturity, shake-out, and decline).

The results of testing the second hypothesis are presented in Table 9 . As can be seen, the ability to predict the future profitability differs through the stages of introduction, growth, maturity, shake-out, and decline. The results showed that from the profitability criteria considered to test the hypothesis, the changes in return of the net operating assets in stages such as introduction and growth, the changes of assets flow in stages such as introduction and growth, return of the net operating assets in the maturity stage, changes in the profit margin and earnings per share in the decline stage, and from the control variables of systematic risk in stages such as maturity and shake-out, firm age and leverage in the decline stage had the ability to predict the future profitability. The highest adjusted identification coefficient was found in the decline stage (41.3\%) and the lowest one was found in the growth stage $(4.1 \%)$

Table 9. Results of testing second hypothesis.

\begin{tabular}{|c|c|c|c|c|c|c|c|c|c|c|c|c|c|c|c|}
\hline \multirow[t]{2}{*}{ Variables } & \multicolumn{3}{|c|}{ Introduction stage } & \multicolumn{3}{|c|}{ Growth stage } & \multicolumn{3}{|c|}{ Maturity stage } & \multicolumn{3}{|c|}{ Shake-out stage } & \multicolumn{3}{|c|}{ Decline stage } \\
\hline & coefficient & $\begin{array}{c}\mathrm{t} \\
\text { statistics }\end{array}$ & P-value & coefficient & $\begin{array}{c}\mathrm{t} \\
\text { statistics }\end{array}$ & P-value & coefficient & $\begin{array}{c}\mathrm{t} \\
\text { statistics } \\
\end{array}$ & P-value & coefficient & $\begin{array}{c}\mathrm{t} \\
\text { statistics }\end{array}$ & P-value & coefficient & $\begin{array}{c}\mathrm{t} \\
\text { statistics }\end{array}$ & P-value \\
\hline$\alpha$ & & -0.699 & 0.486 & & 0.341 & 0.734 & & 1.765 & 0.078 & & 1.289 & 0.201 & & -1.305 & 0.199 \\
\hline (RNOA) & 0.047 & 0.571 & 0.569 & 0.054 & 0.615 & 0.539 & 0.172 & 2.626 & 0.009 & 0.137 & 0.754 & 0.454 & 0.023 & 0.137 & 0.892 \\
\hline$(\triangle R N O A)$ & -0.336 & -5.042 & 0.000 & 0.077 & 0.913 & 0.362 & -0.038 & -0.775 & 0.439 & -0.031 & -0.226 & 0.822 & 0.321 & 2.542 & 0.015 \\
\hline (GRNOA) & -0.004 & -0.059 & 0.953 & 0.036 & 0.503 & 0.616 & -0.080 & -1.645 & 0.101 & -0.052 & -0.396 & 0.693 & 0.066 & 0.511 & 0.612 \\
\hline$(\triangle A T O)$ & -0.190 & -2.682 & 0.008 & -0.131 & -1.701 & 0.090 & -0.065 & -1.248 & 0.213 & 0.052 & 0.372 & 0.711 & -0.137 & -0.902 & 0.372 \\
\hline$(\triangle P M)$ & -0.002 & -0.035 & 0.972 & 0.103 & 1.159 & 0.248 & 0.011 & 0.208 & 0.835 & -0.031 & -0.226 & 0.822 & 0.413 & 3.070 & 0.004 \\
\hline (EPS) & -0.087 & -1.133 & 0.259 & 0.020 & 0.274 & 0.748 & -0.050 & -0.847 & 0.398 & -0.067 & -0.316 & 0.753 & -0.401 & -2.674 & 0.011 \\
\hline (AGE) & -0.097 & -0.358 & 0.176 & 0.020 & 0.266 & 0.791 & 0.026 & 0.517 & 0.606 & -0.118 & -0.953 & 0.344 & 0.265 & 1.931 & 0.060 \\
\hline$(\mathrm{M} / \mathrm{B})$ & 0.020 & 0.270 & 0.787 & -0.037 & -0.477 & 0.634 & -0.022 & -0.393 & 0.695 & 0.084 & 0.519 & 0.606 & 0.016 & 0.117 & 0.908 \\
\hline (LEV) & 0.025 & 0.351 & 0.726 & -0.076 & -1.065 & 0.288 & -0.013 & -0.256 & 0.798 & -0.070 & -0.579 & 0.565 & -0.287 & -1.957 & 0.057 \\
\hline (Beta) & 0.035 & 0.417 & 0.677 & -0.003 & -0.048 & 0.962 & 0.102 & 2.025 & 0.043 & -0.231 & -1.899 & 0.062 & 0.054 & 0.392 & 0.697 \\
\hline (Size) & 0.113 & 1.349 & 0.179 & -0.015 & -0.168 & 0.867 & -0.092 & -1.347 & 0.179 & -0.134 & -0.799 & 0.427 & 0.143 & 0.863 & 0.393 \\
\hline$\delta(R E T)$ & 0.024 & 0.316 & 0.752 & 0.089 & 1.281 & 0.202 & -0.092 & -1.856 & 0.064 & -0.119 & -0.868 & 0.388 & 0.060 & 0.474 & 0.638 \\
\hline $\mathrm{R}^{2}$ & & 0.150 & & & 0.041 & & & 0.043 & & & 0.116 & & & 0.413 & \\
\hline F statistic & & 2.992 & & & 0.747 & & & 1.545 & & & 0.777 & & & 2.467 & \\
\hline P-Value & & 0.001 & & & 0.704 & & & 0.105 & & & 0.672 & & & 0.015 & \\
\hline $\begin{array}{c}\text { Durbin-Wats } \\
\text { on statistic } \\
\end{array}$ & & 2.442 & & & 1.956 & & & 2.070 & & & 1.882 & & & 1.525 & \\
\hline
\end{tabular}




\section{Discussion and Conclusions}

According to the results of the first hypothesis and its minor hypotheses in regression models 1 and 2, the Durbin-Watson statistic was between 1.5 and 2.5. Special amounts and status index were found to be less than 15. In model 1 , given the significant $\mathrm{p}$-value for $t$ statistic of $\beta_{1}, \beta_{2}$, and $\beta_{9}$, the results indicated that RNOA, $\triangle R N O A$ and $\triangle A T O$ had a significant positive $(+2.503)$, negative $(-3.144)$ and negative (-3.097) correlation with the future profitability, respectively. In model 2, RNOA, $\triangle R N O A$ and $\triangle A T O$ had the ability to predict the future profitability with a correlation of $+2.478,-3.366$, and -3.127 , respectively with the future profitability.

The adjustment of changes in assets turnover had a positive effect through the firm's life cycle in stages such as growth and maturity and the adjustment of changes in the profit margin had a positive and meaningful effect through the life cycle in stages such as growth and maturity on the profitability.

In the second hypothesis, and from the criteria of profitability, changes in the return of the net operating assets $(-5.042)$ and changes of the operating assets turnover $(-2.682)$ had the ability to predict the future profitability in the introduction stage. Regarding the meaningfulness level gained for the control variables, none of them had a meaningful coefficient and they did not have the ability to predict the future profitability in the introduction stage. Changes in the operating assets turnover $(-1.701)$ had a negative effect on the future profitability in the growth stage and the control variables did not have the ability to predict the future profitability in this stage. Among the profitability criteria, return of the net operating assets $(+2.626)$ had the ability to predict the future profitability in the maturity stage. It is expected that the profitability criteria have the ability to predict the profitability in the maturity stage. However, the regression test results showed that this hypothesis contradicts with the previous studies statistically. In this research, we considered the current profitability criteria's effect $(t)$ on the profitability of fiscal year $\mathrm{t}+1$. Meanwhile, if it is going to be assessed for year $\mathrm{t}+2$ or more, the ability to predict the variables will enhance. None of the profitability criteria had the ability to predict the profitability in the shake-out stage. In the decline stage, and regarding the meaningfulness level gained, the changes in the return of the net operating assets $(+2.542)$ and changes in the profit margin $(+3.070)$ had positive effects on the future profitability; and, earnings per share (-2.674) had a negative effect. Also, it is expected that the profitability criteria do not have the ability to predict the profitability in the decline stage. But, the results of the regression test showed that this hypothesis contradicts with the previous research work statistically (Table 9). One of the most important reasons for this controversy is that in this research, firms were not in the same stage during the whole time period. For instance, it is likely that a firm could be at the growth stage in a year, but at the shake-out stage in another year. Another reason for the incompatible nature of the variables is due to the time period, statistical samples, and also differences in the economic environment.

\section{REFERENCES}

[1] Hendriksen, E., and Van Berda, M. 1992. Accounting theory. Richard D. Irwin, 5th Edition.

[2] Adizes, I. 1989. Corporate Life Cycle: How and Why Corporations Grow and Die and What Do about it. Englewood Cliffs, NJ.

[3] Dickinson, V. 2011. Cash Flow Patterns as a Proxy for Firm Life Cycle. The Accounting Review 86 (6) 1969-1994.

[4] Nissim, D. and S. Penman. 2001. Ratio analysis and equity valuation: From research to practice. Review of Accounting Studies 6, 109-154.

[5] Anthony, J., \& Ramesh, K. 1992. Association between accounting performance measures and stock prices. Journal of Accounting and Economics, 15(2-3), 203-227.

[6] Aharony, J., Falk, H., and Yehuda, N. 2006. Corporate Life Cycle and the Value Relevance of Cash Flow versus Accrual Financial Information. School of Economics and Management Bolzano, Italy, Working Paper No. 34.

[7] Black, E., L. 1998. Life-cycle impacts on the incremental value-relevance of earnings and cash flow measures. Journal of Financial Statement Analysis, 4, 40-56.

[8] Sugianis, T. 1996. The value Relevancy of Research Development on valuation of future Earnings, Journal of Accounting and Economic, 21, 128-142.

[9] Xu, Bixia. 2007. Life Cycle Effect On the Value Relevance of Common Risk Factor. Review of Accounting and Finance Vol. 6, 162-175.

[10] Gort, M., \& Klepper, S. 1982. Time paths in the diffusion of product innovation. Economic Journal, 92, 630-653.

[11] Brooks, L., \& Buckmaster, D. 1976. Further evidence on the time series properties of accounting income. Journal of Finance, 31(5), 1359-1373.

[12] Fairfield, P., Sweeney, R., and Yohn, T. 1996. Accounting classification and the predictive content of earnings. The Accounting Review, 71, 337-355.

[13] Fama, E. F., \& French, K., R. 2000. Forecasting profitability and earnings. Journal of Business, 73, 161-175.

[14] Freeman, R., Ohlson, J., and Penman, S. 1982. Book rate-of-return and prediction of earnings changes: An empirical investigation. Journal of Accounting Research, 20, 639-653.

[15] Haghighat, H., \& Ghorbani, A. 2007. Assessed and compared information content of two performance measures of profit and cash flows regarding firm value. Journal of Management, 21-22, 201-219.

[16] Dehdar, F. 2007. The effect of life cycle on increasing descriptive ability of valuating patterns based on profit and 
accruals compared with patterns based on operating cash flows, investment, and financing. PhD Thesis University of Tarbiyat Moddares.

[17] Omrani, H., \& Karami, Gh. 2010. The effect of firm's life cycle and conservatism on firm value. Journal of financial accounting, 3(5), 49-64.

[18] Rahmani, A., \& Mousavi, S. 2011. The relationship between profitability and stock return regarding life cycle and firm size. Journal of accounting and auditing researches, 9, 83-100.

[19] Park, Y., \& Chen, K. 2006. The Effect of Accounting Conservatism And Life -Cycle Stages On Firm Valuation,
Journal of Applied Business Research, 22, 75-92.

[20] Thanatawee, Y. 2011. Life cycle theory and free cash flows of dividends policies in firms enlisted in Stock Exchange in Thailand. Journal of Elsevier, 31, 129- 151.

[21] Fairfield, P., Sweeney, R., and Yohn, T. 2001. Using asset turnover and profit margin to forecast changes in profitability. Review of Accounting Studies, 6, 371-385.

[22] Penman, S., \& Zhang, X. 2006. Modeling sustainable earnings and $\mathrm{P} / \mathrm{E}$ Ratios with financial statement analysis. Working paper, Columbia University and University of California, Berkeley, USA. 